\title{
A case report of renal cell carcinoma in a dog
}

[Um relatório do caso de carcinoma de células renais em um cão]

\author{
A.-S., Paşca*, M. Lazăr \\ University of Agricultural Sciences and veterinary Medicine Iasi - Faculty of Veterinary Medicine \\ 3, Mihail Sadoveanu Alley, 700490, Iaşi, Romania
}

\begin{abstract}
Mix renal carcinoma was noticed during the necropsic examination of a 14 year old mix breed female. Tumours were bilateral and metastasis was noticed in the spleen and myocard. Histological examination evidenced morphological aspects characteristic to the mixt renal carcinoma. Histological aspects described in this individual characterize renal cell carcinoma, also known as renal adenocarcinoma, hypernephroma or, in older literature, Grawitz tumour.
\end{abstract}

Keywords: dog, renal carcinoma, pathology

\section{RESUMO}

Carcinoma renal misto foi observado durante necrópsia de uma fêmea de raça mista de 14 anos. Os tumores eram bilaterais. Mais do que isso, a metástase foi observada no baço e no miocárdio. $O$ exame histológico evidenciou aspectos morfológicos característicos de carcinoma renal misto. Aspectos histológicos descritos neste indivíduo caracterizam carcinoma de células renais, também conhecido como adenocarcinoma renal, hipernefroma ou, na literatura mais antiga, como tumor Grawitz.

Palavras-chave: cão, carcinoma renal, patologia

\section{INTRODUCTION}

The renal carcinoma is the most common primary renal parenchymal tumour in humans, and it has also been reported in cats, dogs, cattle, sheep and horses, rabbits, rats, mice, monkeys, batrachians, etc. It develops in adult or old animals, at the average age of 8 years in the case of dogs, with a predisposition for the male gender (the proportion is of 2/1-3/2 compared with the female gender) and it equally affects the left and right kidney, but in exceptional cases it can affect both kidneys. Some etiologic factors are: aromatic hydrocarbures, amines and amides, urethane, aflatoxins and hormones.

The primary site of tumour is the cortical tissue, usually the lower pole. At first, the tumour is very small, asymptomatic, incidentally discovered during necropsy, but it may reach enormous dimensions, up to a diameter of $15-20 \mathrm{~cm}$, weighing several pounds. Larger tumours are round or ovoid and have the multilobular appearance of conglomerate lobules, well-delimited, apparently encapsulated; on the section surface they can have a microcystic aspect, requiring a differentiation from the polycystic kidney. The colour varies: there are pink-greyish areas alternating with whitish and solid areas, corresponding to less differentiated masses, yellow areas loaded with lipids, red-brown outbreaks of haemorrhagic necrosis, small or large cretaceous outbreaks and yellowish myxoid areas. The tumour also presents white connective tissue structure. The growth of the tumour is expansive, causing the compression atrophy of the renal tissue. Other small satellite nodules can be detected in the renal parenchyma, adjacent to the primary tumour, as a result of local tumour infiltrations. It

Recebido em 14 de fevereiro de 2013

Aceito em 6 de agosto de 2013

E-mail: passorin@yahoo.com

Financial support: UEFISCDI Romania - Research Program TE 112/2010 
can extend into the renal veins where it forms tumoural thrombi not necessarily metastatic, but witch may disseminate in the adrenal glands, the congener kidney or remotely in the lungs, skeleton, liver, colon, diaphragm or mammary gland (particularly the clear-cell type). Secondary locations in the lungs are associated with a hypertrophic osteoarthropathy (Tsuda et al., 1992).

Microscopically, according to the predominant type of cell hyperplasia, the tumours are classified as: clear cell carcinomas, granular cell carcinomas (basophiles or acidophiloeus) and mixt carcinomas (Tavassoli et al., 2003).

According to the arrangement of the cells, renal carcinoma may be: hollow (glandular), trabecular, tubulo-papillary, solid (massive, compact), cystic or mixt (combined).

In terms of histology, they are grouped in differentiated, poorly differentiated and undifferentiated carcinomas.

The stroma is modest, consisting of fibrous tissue and numerous capillaries.

\section{CASUISTRY}

Following necropsic examination, organ samples were prelevated for histopathological investigations. Each case had prelevated kidney fragments, as well as fragments from different organs, physiologically related (heart, liver, lung, intestine, spleen, etc.).

Organ samples were fixated in $10 \%$ formaldehyde, then embedded in paraffin. Histological sections measuring $5 \mu \mathrm{m}$ were stained Haematoxilin - Eosin - Methyl Blue (Tricromic - Masson).

\section{DISCUSSION}

The tumour was identified during the necropsic examination of a half-breed female dog, 14 years old.

Tumoural formations were nodular, with diameters ranging between 1 and $2.5 \mathrm{~cm}$, proeminent under the capsule, with a convex smooth section area, slightly uneven and with clear edges separating it from the adjacent cortex (Figure 1).

Microscopically, a peripheric pseudocapsule can be noticed, consisting of fibrous tissue condensed by the tumour expansion with atrophy of the peritumoural renal tissue and a connective clamp subdivision which gives it an appearance of multilobular conglomerate.

The tumour parenchyma is organized in different architectural structures: compact beaches (massive), alveolar areas, simple tubes (Figure 2) or with micro-papillary and/or papillary protrusions, cords and trabecules with a poorly represented tumoural stroma.

The compact (massive or solid) areas are represented by clear beaches of neoplastic cells (such as the classic type of carcinoma renal cells) alternating with haemorrhagic necrosis areas and hyperaemic blood vessels (Figure 3).

The neoplastic cells are clear (such as the classic type of renal carcinoma cells) in over $90 \%$ of the cases. These are large polygonal, vacuolized cells with the cytoplasm reduced to a thin layer under the cell membrane and small hyperchromatic nuclei, either with central or peripheric locations. Mitosis is rare. According to the bibliography, the vacuoles contain lipids and cholesterole (highlighted by the freezing embedding technique and by special staining methods) and glycogen; the latter, water-soluble, is removed during fixation, embedding and common staining methods, so the PAS response remains weakly positive or negative (Reed et al., 1983; Stenzel et al., 1989; Steffens et al., 1990; Weiss et al., 1995).

In the predominantly glandular areas, the tumoural-tubules derived from proximal convoluted segments are wallpapered with cubic or columnar cells, mono or pluristratified, with varying degrees of squamous metaplasia, where the cells are polygonal, with bridges and a tendency to concentric stratification and keratinisation. Several microcysts can be observed scattered between the neoplastic cells (Lium et al., 1985) (Figure 4 and 5).

In the tubes, but also in the cords, trabeculae or tumoural islands, certain oncocythic transformations occur. The neoplastic cells have 
a variety of sizes and shapes and slightly polymorphic nuclei. The most important cytological aspects of this type of carcinoma are represented by the acidophile's abundant cytoplasm with numerous uniform eosinophilic granules (Figure 6). These intensely acidophilous and granular cells having small and regulated nuclei and a very small N/c ratio, are called oncocytes. The granules of the cytoplasm are represented by the proliferated mitochondria occupying almost the entire cytoplasm, which does not always present an unaltered structure. The oncocytic tumour is called oncocytom and may have a benign or malignant evolution, with disseminations.

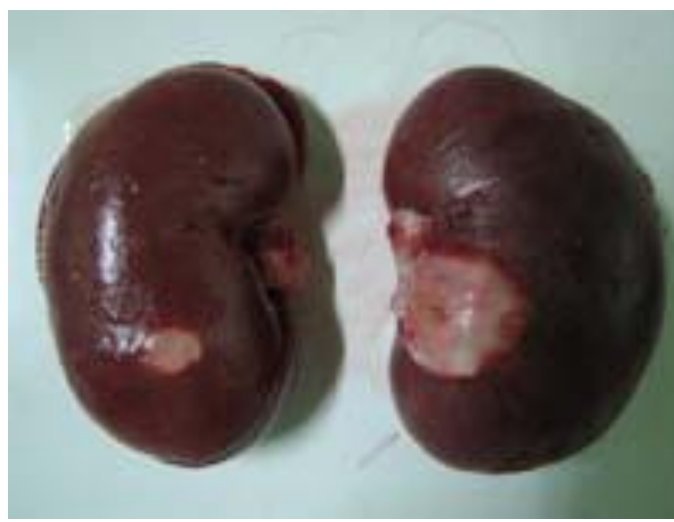

Figure 1. Dog. Bilateral mixt renal carcinoma.

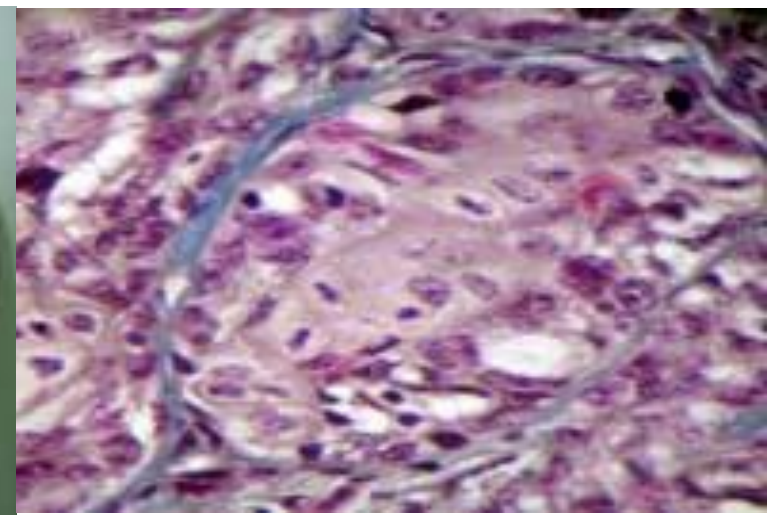

Figure 2. Dog. Kidney. Carcinoma. Pleomorph tubular carcinoma; mitosis. Col. HEA, x900

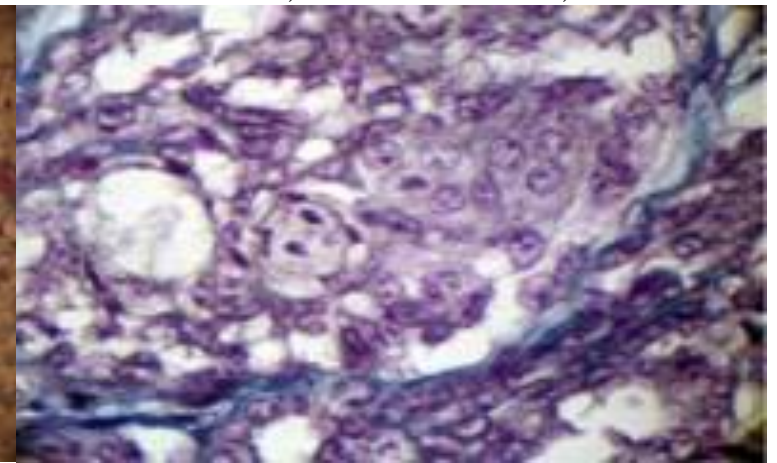

Figure 3. Dog. Kidney. Renal adenocarcinoma. Islands of clear cells, hemorrhagic necrosis and collagen septae. Col. HEA x200

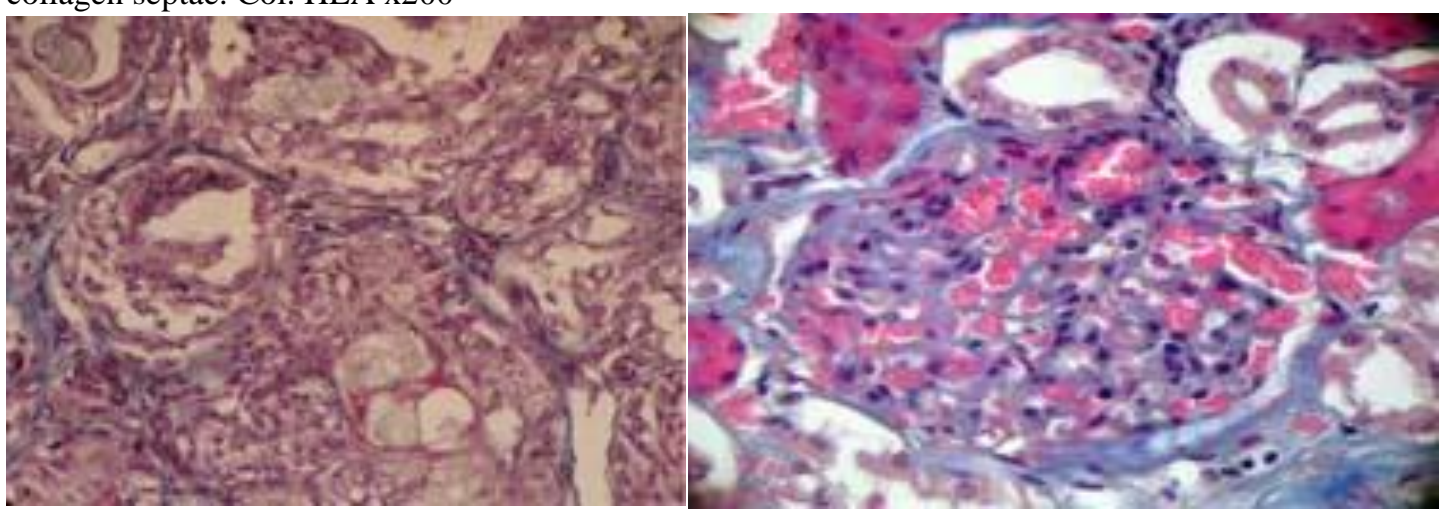

Figure 5. Dog. Kidney. Carcinoma. Tubulopapillary proliferation, squamous metaplasia. Col. HEA, x900
Figure 4. Dog. Kidney. Carcinoma. Pleomorphism, mitosis, microcysts. Col. HEA, 1000
Figure 6. Dog. Kidney. Area of cells with oncocytic transformation. Col. HEA, x400 
In other areas of the renal tumours, there are pure micro-papillary epithelial protrusions or papillary protrusions made of small rods of loose connective tissue covered with a monolayer of small, cubic neoplastic cells, with hyperchromatic nuclei and rare mitotic figures, developed in a cellular or hollow space.

Finally, we can observe areas with a myxoid aspect consisting of cords, trabeculaes and small islands of pleiomorphic, spindly, triangular or stellar cells with anisocytosis, several mitotic and syncytial figures, corresponding to a less differentiated carcinoma (Figure 7).

The histological aspects described in this case feature the renal cell carcinoma, also known as renal adenocarcinoma names, hypernephroma or, in older literature, as the Grawitz tumour. The renal carcinoma has multiple aspects and although one can find tumours consisting of a single cell type, most often they are associated with different areas, with particular cell types and varying degrees of differentiation.

The tumoural mass invades the renal capsule and the connective perirenal tissue, forming papillary protrusions on the kidney surface (Figure 8).

Literature indicates that, at least in human patients, the renal adenocarcinoma disseminates by local infiltration not only at the perirenal level, but also in the basin, and on the hematogenous way as well (with tumour thrombus formation in the renal vessels in about $30 \%$ of the cases in stage III) or through lymphatic circulation, with the infiltration of the regional limphonodes (Eble et al., 1986; Jonasdottir et al., 2000)

Splenic (subcapsular) and myocardic (right atrium) carcinoma metastasis have been also identified (Figure 9 and 10).

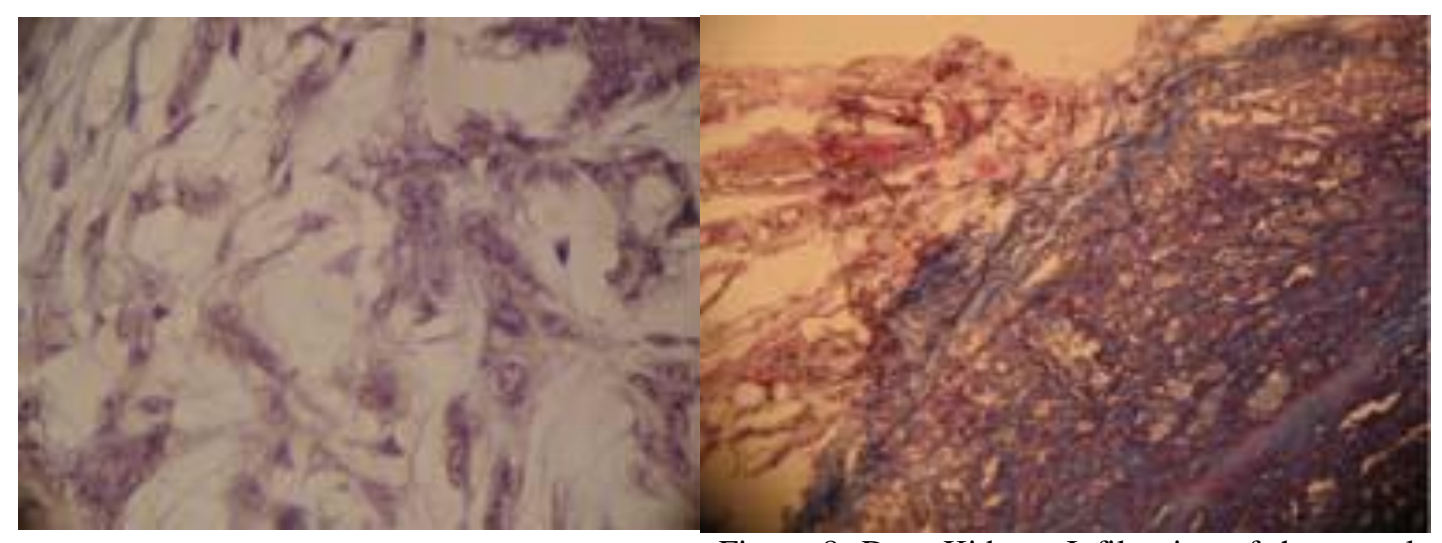

Figure 7. Dog. Kidney. Myxoid aspect. Col. HEA, x900

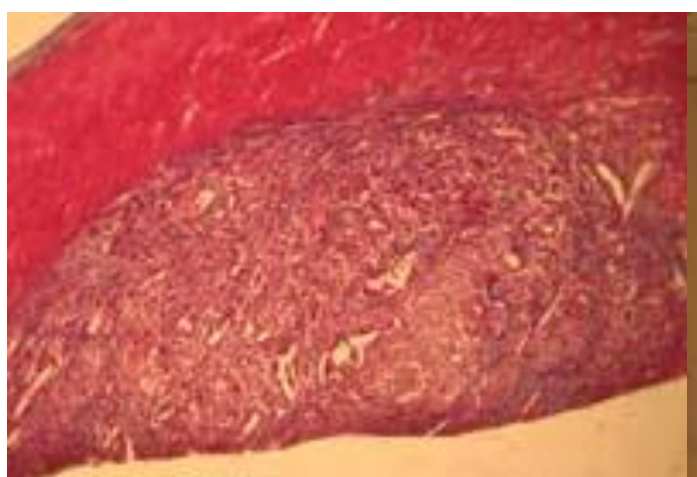

Figure 9. Dog. Myocard. Carcinomatous metastasis. Col. HEA, x60
Figure 8. Dog. Kidney. Infiltration of the capsule and of the perirenal tissue.

Col. HEA, x60 


\section{CONCLUSIONS}

The myxoid aspect consists of cords, trabeculaes and small islands of pleiomorphic cells (spindly, triangular or stellar) with anisocytosis, several mitotic and syncytial images, corresponding to a less differentiated carcinoma. The renal carcinoma has multiple aspects and although one can find tumours consisting of a single cell type, most often they are associated with different areas, with particular cell types and varying degrees of differentiation.

\section{ACKNOWLEDGMENTS}

The authors thank UEFISCDI Romania for the financial support (Research Program TE 112/2010).

\section{REFERENCES}

EBLE, J.N.; HULL, M.T. Morphologic features of renal oncocytoma - A light and electronmicroscopic study. Hum. Pathol., v.15, p.1054-1061, 1986.

JONASDOTTIR, T.; MELLERSH, C.; MOE, L. et al. Genetic mapping of a naturally occurring hereditary renal cancer syndrome in dogs. Proc. Natl. Acad. Sci., v.97, p.4132-4137, 2000.
LIUM, B.; MOE, L. Hereditary Multifocal Renal Cystadenocarcinomas and Nodular Dermatofibrosis in the German Shepherd dog: Macroscopic and Histopathologic Changes. Vet. Pathol., v.22, p.447455, 1985.

REED, R.J.; LOVE, G.L.; HARKIN, J.C. Clear cell carcinoma. Am. J. Surg. Pathol., v.7, p.597-601, 1983.

STEFFENS, J.; BOCK, R.; BRAEDEL, H.U. Isenberg E, Bührle CP, Ziegler M. Renin-producing renal cell carcinoma. Eur. Urol., v.18, p.56-60,1990.

STENZEL, A.; KERNION, J.B. Pathology, biology and clinical staging of renal cell carcinoma. Semin. Oncol., v.16, p.3-11, 1989.

TAVASSOLI, F.A.; DEVILLE, P. Pathology and Genetics: Tumours of the breast and female genital organs - World Health Organisation Classification of Tumours. Lyon: International Agency for Research on Cancer Press, 2003. p.9-112.

TSUDA, H.; KRIEG, K. Neoplastic Lesions in the Kidney. In: Pathobiology of the Aging Rat. MOHR, U.; DUNGWORTH, D.L.; CAPEN, C.C. v.1, Washington: ILSI Press, 1992. p.235-237.

WEISS, L.M.; JEBB, A.B.; MEDEIROS, L.J. Adult renal epithelial neoplasms. Am. J.Clin. Pathol., v.103, p.624- 635, 1995. 